\title{
Liana infestation impacts tree growth in a lowland tropical moist forest
}

\author{
G. M. F. van der Heijden and O. L. Phillips \\ Ecology and Global Change, School of Geography, University of Leeds, UK \\ Received: 16 December 2008 - Published in Biogeosciences Discuss.: 18 March 2009 \\ Revised: 14 September 2009 - Accepted: 28 September 2009 - Published: 16 October 2009
}

\begin{abstract}
Ecosystem-level estimates of the effect of lianas on tree growth in mature tropical forests are needed to evaluate the functional impact of lianas and their potential to affect the ability of tropical forests to sequester carbon, but these are currently lacking. Using data collected on tree growth rates, local growing conditions and liana competition in five permanent sampling plots in Amazonian Peru, we present the first ecosystem-level estimates of the effect of lianas on above-ground productivity of trees. By first constructing a multi-level linear mixed effect model to predict individual-tree diameter growth model using individual-tree growth conditions, we were able to then estimate stand-level above-ground biomass (AGB) increment in the absence of lianas. We show that lianas, mainly by competing aboveground with trees, reduce tree annual above-ground standlevel biomass increment by $\sim 10 \%$, equivalent to $0.51 \mathrm{Mg}$ dry weight $\mathrm{ha}^{-1} \mathrm{yr}^{-1}$ or $0.25 \mathrm{Mg} \mathrm{C}^{-1} \mathrm{yr}^{-1}$. AGB increment of lianas themselves was estimated to be $0.15 \mathrm{Mg}$ dry weight $\mathrm{ha}^{-1} \mathrm{yr}^{-1}$ or $0.07 \mathrm{Mg} \mathrm{C} \mathrm{ha-1} \mathrm{yr}^{-1}$, thus only compensating $\sim 29 \%$ of the liana-induced reduction in ecosystem AGB increment. Increasing liana pressure on tropical forests will therefore not only tend to reduce their carbon storage capacity, by indirectly promoting tree species with low-density wood, but also their rate of carbon uptake, with potential consequences for the rate of increase in atmospheric carbon dioxide.
\end{abstract}

\section{Introduction}

Lianas are woody climbers that are important and characteristic components of tropical forests (Gentry, 1991). Lianas rely mainly on trees to support their biomass and, as a conse-

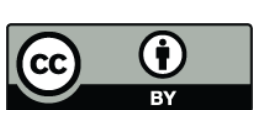

Correspondence to:

G. M. F. van der Heijden

(g.m.f.vanderheijden@googlemail.com) quence, can be detrimental for host trees by enhancing their mortality risk (Putz, 1984; Phillips et al., 2005) and reducing their fecundity (Stevens, 1987; Kainer et al., 2006). Additionally, there is also considerable evidence that lianas suppress individual-tree growth (Putz, 1984; Clark and Clark, 1990). Several studies showed an effect of lianas on tree growth by experimental removal of lianas (Whigham, 1984; Pérez-Salicrup and Barker, 2000; Gerwing, 2001; Grauel and Putz, 2004; Campanello et al., 2007), whilst others compared growth rates of juvenile trees in the presence and absence of lianas (Dillenburg et al., 1993a, b; 1995; Schnitzer et al., 2005).

Lianas are apparently effective above-ground competitors (Stevens, 1987; Campbell and Newbery, 1993), as they can severely affect the light availability by forming a monolayer of leaves over the tree crown (Avalos et al., 1999). However, with their well developed root (Restom and Nepstad, 2004; Cai et al., 2007) and efficient vascular systems (Ewers and Fisher, 1989; Fisher and Ewers, 1995), and high root extension rate, enabling rapid colonisation of resource-rich patches of soil (Putz, 1991), it has been suggested that lianas may also be successful below-ground competitors. Only few studies have attempted to disentangle the effects of aboveand below-ground liana competition. These generally indicate that below-ground competition for water and nutrients is the dominant mechanism by which lianas affect tree growth (Dillenburg et al., 1993a, b, 1995; Pérez-Salicrup and Barker, 2000; Schnitzer et al., 2005; Toledo-Aceves and Swaine, 2008), and this forms bans for a theory on liana success (Schnitzer, 2005). However, most of these studies have focussed on juvenile trees; adult trees may respond differently (Barker and Pérez-Salicrup, 2000). To date, no attempt has been made to separate the relative importance of aboveand below-ground liana competition on tree growth for trees $\geq 10 \mathrm{~cm}$ diameter, which contribute $>90 \%$ of forest biomass (Baker et al., 2004a).

Published by Copernicus Publications on behalf of the European Geosciences Union. 
Lianas have been increasing in density, basal area, mean size, leaf productivity and fecundity in neotropical forests over the past few decades (Phillips et al., 2002; Wright et al., 2004; Wright and Calderon, 2006), as a result of changing atmospheric conditions (e.g. Granados and Körner, 2002; Malhi and Wright, 2004; Phillips et al., 2004) and/or in response to other human influences upon tropical forests (Wright et al., 2007). As lianas become more dominant, their impacts on tree growth and mortality may decrease the ability of tropical forests to store and sequester carbon. To be able to better predict the response of tropical forests to environmental change and anthropogenic disturbance, stand-level estimates of the effect of lianas on above-ground biomass increment of tropical forests are needed. However, whilst the negative effect of lianas on tree growth is generally accepted, the carbon dynamics of lianas themselves have largely been ignored. We therefore do not know the extent to which growth of lianas may have compensated for a reduction in growth in tree biomass, although the relatively small investment by lianas in woody support tissue (Putz, 1983; Gehring et al., 2004; Cai et al., 2007; Selaya et al., 2007) might suggest that such compensation will also be small. Moreover, most studies have focussed on only one or a few tree species (e.g. Putz, 1984; Barker and Pérez-Salicrup, 2000; Pérez-Salicrup and Barker, 2000; Grauel and Putz, 2004; Campanello et al., 2007), complicating ecosystem generalisations. Stand-level estimates of the effect of lianas on tree growth in mature tropical forest ecosystems are currently completely lacking.

To this end, we made liana-infestation assessments in an intensely-studied forest site in Amazonian Peru for which long-term records of growth and species composition for trees and lianas $\geq 10 \mathrm{~cm}$ diameter are available. We combined growth records with individual tree growth conditions and liana dominance, in order to assess the effect of lianas on tree growth whilst also accounting for light availability, below-ground competition with neighbours and wood density (e.g. Casper and Jackson, 1997; Muller-Landau, 2004; King et al., 2005; Coomes and Allen, 2007). This study presents the first attempt to: (1) predict the effect of lianas on individual tree diameter growth using a multi-species model; (2) disentangle above-ground from below-ground competition with lianas; (3) estimate the effect of liana competition on stand-level tree above-ground biomass increment; and (4) estimate to what extent growth of lianas compensates for this effect.

\section{Methods}

\subsection{Study site}

This study was conducted in five 1 -ha $(100 \times 100 \mathrm{~m})$ permanent sample plots of the RAINFOR project (Red Amazónica de Inventarios Forestales; Amazon Forest Inventory Network; http://www.rainfor.org) which are spread across the
Tambopata Nature Reserve, Madre de Dios, Peru, in western Amazonia $\left(12^{\circ} 48^{\prime} \mathrm{S}, 69^{\circ} 43^{\prime} \mathrm{W}\right)$. The plots receive a mean annual rainfall of $2248 \mathrm{~mm}$, with three months averaging below $100 \mathrm{~mm}$ (Clinebell et al., 1995), and are located mainly on clay and sandy-clay ultisols and inceptisols, at approximately $260 \mathrm{~m}$ above sea level (for more details see Phillips et al., 2004). Most of the plots were established in 1983, and have 140-180 species of tree $\geq 10 \mathrm{~cm}$ diameter (Gentry, 1988). All trees and lianas $>10 \mathrm{~cm}$ diameter in the plots are tagged and remeasured every three to five years, with the most recent measurements between November 2005 and April 2006 (for details on census methodology see e.g. Baker et al., 2004a).

\subsection{Tree growth rates}

Inventory data were available for an approximately three year census period (2003-2006) for all five plots, with diameter measured for each trees $\geq 10 \mathrm{~cm}$ at $1.30 \mathrm{~m}$ or above buttresses $(\mathrm{dbh})$. Diameter growth rates $\left(\mathrm{mm} \mathrm{yr}^{-1}\right)$ were determined arithmetically by dividing the difference in diameter between the first and the second census by the exact census interval in years. Following Sheil (1995), we considered diameter changes between -2 and $40 \mathrm{~mm} \mathrm{yr}^{-1}$ as acceptable and excluded trees with diameter growth rates outside this range. We also omitted all palms, as they lack diameter growth after the initial establishment period because of their limited capacity for secondary growth (Tomlinson, 1979).

\subsection{Liana competition}

The liana census took place between September 2005 and January 2006, approximately three months before the latest full tree census. For each tree $\geq 10 \mathrm{~cm} \mathrm{dbh}$, we recorded all lianas $\geq 1 \mathrm{~cm}$ diameter entering and leaving the tree crown, and all lianas rooting within one metre from the tree trunk. The diameter of liana stems was measured at $1.30 \mathrm{~m}$ from the last rooting point with a calliper or with a diameter tape for stems thicker than $10 \mathrm{~cm}$ diameter (cf. Gerwing et al., 2006). For lianas with irregular stems, the diameter was measured in two perpendicular dimensions and the geometric mean used (Gerwing et al., 2006). For lianas which infested the tree crown, but for which the rooting point could not be determined, and for lianas leaving the tree crown, the diameter was estimated using $1 \mathrm{~cm}$ size-classes at the point where they entered or left the tree crown and we used the midpoint of the size-class as a diameter estimate in further analyses. Hemi-epiphytes and climbing monocots (Poaceae, Arecaceae, Araceae and Cyclanthaceae) were excluded. Furthermore, woody climbers were not separated from non-woody climbers, because of the difficulties in distinguishing juvenile lianas from herbaceous climbers.

The leaf area of lianas present in the tree crown can be used as a measure of above-ground competition with lianas. Liana size is directly related to liana leaf area and biomass 
(Putz, 1983; Gerwing and Farias, 2000; Gehring et al., 2004). However, as liana stems often grow from tree crown to tree crown (e.g. Putz, 1984b), their leaf area and biomass may be spread over more than one tree. Simply using the basal area of lianas entering the tree crown would therefore overestimate the liana presence in a tree crown. We corrected for this by subtracting the basal area of lianas growing out of the tree crown $\left(b a_{\text {out }}, \mathrm{cm}^{2}\right.$; on average of $7.4 \%( \pm 0.5$ S.E. $)$ of liana basal area entering the tree crown) from that of liana growing into the tree crown $\left(b a_{\mathrm{in}}, \mathrm{cm}^{2}\right)$; providing a more accurate estimate of liana leaf area in the crown than using lianas growing into the tree crown only.

No information is available about below-ground competition between adult lianas and trees, we therefore assumed that lianas rooted within a radius of one metre from the tree were competing below-ground with the tree and used the sum of the basal area of these lianas as a measure for belowground competition $\left(\mathrm{ba}_{1 \mathrm{~m}}, \mathrm{~cm}^{2}\right)$. As tree size, at least partially, reflects the competitive ability of a tree (Schwinning and Weiner, 1998), we have adjusted the liana basal area per tree for tree basal area $\left(b a_{i}\right.$ in $\left.\mathrm{cm}^{2}\right)$ to obtain a liana competition measure for above-ground competition $\left(\mathrm{AC}_{L}\right.$, $\left.\mathrm{cm}^{2} \mathrm{~cm}^{-2}\right)$ or below-ground competition $\left(\mathrm{BC}_{L}, \mathrm{~cm}^{2} \mathrm{~cm}^{-2}\right)$ which is independent of tree size:

$$
\begin{aligned}
\mathrm{AC}_{L} & =\sum\left(b a_{\text {in }}-b a_{\text {out }}\right) / b a_{i} \\
\mathrm{BC}_{L} & =\sum\left(b a_{1 m}\right) / b a_{i}
\end{aligned}
$$

\subsection{Measures of growth conditions}

\subsubsection{Light environment}

For each tree $\geq 10 \mathrm{~cm} \mathrm{dbh}$, the quantity of solar radiation received by the tree crown was estimated using the Crown Illumination Index (CII) (Clark and Clark, 1992), recorded independently by two observers. The CII consists of an ordinal scale of 1 to 5, with high CII values indicating high light levels. Canopy openness and direct site factors are closely related to the CII, which makes it a rapid and reliable method to estimate the light environment of tree crowns (Davies et al., 1998; Keeling and Phillips, 2007). The two observers' estimates of the CII were highly correlated and did not differ significantly (Kendall's index of concordance $=0.91, P<0.001$ ). For subsequent analyses, where they differed, the lower CII estimate was used to be more conservative.

\subsubsection{Below-ground competition with neighbouring trees}

Tree growth may also be influenced by the extent of belowground competition. Competition between neighbouring trees is proportional to the size of the tree and decreases with increasing distance from the target tree (Casper and Jackson, 1997). We therefore used a simple basal area-distance competition index to describe the extent of below-ground com- petition with neighbouring trees $\left(\mathrm{BC}_{T}, \mathrm{~cm}^{2} \mathrm{~cm}^{-2}\right)$ growing within a $10 \mathrm{~m}$ radius from the subject tree (cf. Lorimer, 1983):

$\mathrm{BC}_{T}=\sum\left(b a_{j} / d_{i j}\right) / b a_{i}$

where $b a_{i}$ and $b a_{j}$ are the basal area of the subject neighbouring tree, respectively, and $d_{i j}$ is the distance from the neighbouring tree to the subject tree. To avoid edge effects, we included trees growing within a $10 \mathrm{~m}$ buffer zone surrounding the plot, for which diameter and location was also collected.

\subsubsection{Wood density}

Wood density is a heritable characteristic and an intrinsic measure of species-specific growth rate; tree species with low-density wood grow faster and those with high wood density wood grow slower (Enquist et al., 1999; Muller-Landau, 2004; King et al., 2005; Chave et al., 2006). Species-specific wood density values $\left(\rho, \mathrm{g} \mathrm{cm}^{-3}\right)$ were obtained from Chave et al. (2006). When unavailable, genus- or family-level mean values were used, following convention (e.g. Baker et al., $2004 b)$. For the 13 individual trees $(0.59 \%)$ with no familylevel wood density data, we applied the overall species mean for Tambopata of $0.64 \mathrm{~g} \mathrm{~cm}^{-3}$.

\subsection{Liana above-ground biomass increment}

As part of the plot recensus protocol, the diameter of all liana stems $\geq 10 \mathrm{~cm}$ are measured at $1.30 \mathrm{~m}\left(d_{\mathrm{vert}}\right)$ above the ground and at the widest point within $2.5 \mathrm{~m}$ above the ground $\left(d_{\max }\right)$. To be able to estimate the contribution of liana growth to the total AGB increment, we have focussed here on lianas $\geq 10 d_{\max }$ present in both the 2003 and 2006 recensus only. For each liana $\geq 10 \mathrm{~cm} d_{\max }$, we converted the $d_{\text {vert }}$ into the diameter $1.3 \mathrm{~m}$ along the stem $(d 1.3)$ for each census and used this diameter to calculate the liana aboveground biomass (LAGB, Mg) (Schnitzer et al., 2006):

$$
\begin{aligned}
& d 1.3=0.070+1.02 * d_{\text {vert }} \\
& \text { LAGB }=\exp ^{(-1.484+2.682 * d 1.3)} / 1000
\end{aligned}
$$

Based on the LAGB values, the liana above-ground productivity per plot $\left(\mathrm{Mg} \mathrm{ha}^{-1} \mathrm{yr}^{-1}\right)$ was computed. A recent study in TAM-05 indicated that the AGB of lianas $\geq 10 \mathrm{~cm} d_{\max }$ contributed to $57 \%$ of the total AGB of lianas $\geq 1 \mathrm{~cm} d_{\text {vert }}$ per ha (Phillips et al., 2005). We used this percentage to obtain an estimate of liana AGB and above-ground productivity of lianas $\geq 1 \mathrm{~cm} d_{\text {vert }}$ in each of the plots.

\subsection{Data analysis}

Our dataset exhibited a hierarchical structure with multiple levels - individual trees, which are grouped in plots, but also in species which are nested within genera which are nested 
within families - which can contravene assumptions of independence of a general linear model (Gelman and Hill, 2007). To take account of these correlated measures, we constructed a multi-level Linear Mixed Effect (LME) model to predict individual tree growth rate $\left(g r, \mathrm{~mm} \mathrm{yr}^{-1}\right)$. Multilevel models include covariates (the fixed effects) for the individual level and the group levels and random effects to represent both the unexplained variation within levels and unexplained variation between levels. They contain two types of models: 1) a model in which coefficients are based upon all the data combined, similar to a normal multivariate regression model (the fixed effect model), and 2) a separate submodel for each level (Gelman and Hill, 2007; Goldstein, 2003). By including phylogeny and plot as random effects in the regression models, we thus account for the impact of variation in these properties on individual-tree growth rates.

In our multi-level LME model, we included initial tree diameter $\left(D_{t o}, \mathrm{~mm}\right), \mathrm{CII}$, wood density $(\rho)$, below-ground competition with neighbouring trees $\left(\mathrm{BC}_{T}\right)$ and liana aboveground $\left(\mathrm{AC}_{L}\right)$ and below-ground $\left(\mathrm{BC}_{L}\right)$ competition as fixed effects and phylogeny - as a nested design of family $\left(\alpha_{f}\right)$, genera within families $\left(\alpha_{g f}\right)$, and species within genera within families $\left(\alpha_{s g f}\right)$ - and plot $\left(\alpha_{\text {plot }}\right)$ as random effects:

$$
\begin{aligned}
\ln (g r+2)_{i}= & \mu+\beta_{1} \ln \left(\mathrm{AC}_{L}+0.01\right)_{i} \\
& +\beta_{2} \ln \left(\mathrm{BC}_{L}+0.01\right)_{i}+\beta_{3} \ln \left(D_{t 0}\right)_{i} \\
& +\beta_{4} \rho_{i}+\beta_{5} \ln \left(\mathrm{BC}_{T}\right)_{i} \\
& +\beta_{6} C I I_{i}+\alpha_{f[i]}+\alpha_{g f[i]}+\alpha_{s g f[i]} \\
& +\alpha_{\text {plot }[\mathrm{i}]}+\varepsilon
\end{aligned}
$$

where $\mu$ indicates the intercept and $\varepsilon$ represent the residual variance and all random effects ( $\alpha$ 's) have mean 0 and variance $\sigma_{\alpha}^{2}$. To meet the normality and linearity assumptions, gr, $D_{t 0}, \mathrm{AC}_{L}, \mathrm{BC}_{L}$ and $\mathrm{BC}_{T}$ were all transformed using the natural $\log$. The model parameters were estimated using Restricted Maximum Likelihood (REML) (McCulloch and Searle, 2001).

The contribution of each fixed and random effect was assessed by deleting variables one at a time from the full model and comparing the depleted models with the full model using an $\chi^{2}$-test based on the log-likelihood ratios (Pinheiro and Bates, 2000) and the Akaike Information Criterion (AIC), favouring models with low AIC (Burnham and Anderson, 2002). Inclusion of interaction or polynomial terms did not significantly improve the model nor did it result in a reduction of the AIC. Model fit was assessed by evaluating residual plots and by testing for presence of spatial autocorrelation in the residuals using the Moran's $I$ for each plot separately (Moran's $I<0.015$ for all plots) (Pinheiro and Bates, 2000; Gelman and Hill, 2007).

The resulting "best" model was subsequently used to assess the impact of lianas on ecosystem above-ground biomass (AGB) increment of trees $\geq 10 \mathrm{~cm} \mathrm{dbh}$. We used the "best" model to predict tree diameter growth rates for a situation in which none of the trees were competing with lianas, i.e. by setting the liana competition part in the model to zero for all trees. Subsequently, for each model, we converted the predicted growth rates into tree diameter at breast height $(D, \mathrm{~cm})$ at the time of the second census. These diameters and those from the 2003 census were used to calculated tree AGB (Mg dry weight) for each census and AGB increment (Mg dry weight $\mathrm{ha}^{-1} \mathrm{yr}^{-1}$ ) using the equation by Chave et al. (2005) for moist forests:

AGB $=0.0509\left(\rho D^{2} h\right) / 1000$

where $h$ is tree height (m), which was calculated using a locally derived diameter-height equation (Baker et al., 2007):

$h=8.27 \ln (D)-8.85$

We then compared AGB increment of the model predicting the current situation with that of the model predicting a situation where lianas are absent using paired t-tests for each plot separately and for all plots combined.

Trees with incomplete species identification $(11 \%$ of total number of trees) were initially excluded from both model runs. We estimated their growth rate afterwards using the fixed effect models, unless family and/or genus-level information was available, in which case the relevant random effects were also included.

All statistical analyses were carried out using R 2.8.0 (R Development Core Team, 2008).

\section{Results}

\subsection{Liana competition}

Of the 2159 trees inventoried, $50.9 \%$ were competing with lianas: $5.0 \%$ only below-ground, $25.8 \%$ only above-ground and $20.5 \%$ above- and below-ground. Liana basal area in the tree crown ranged from 0 to $658 \mathrm{~cm}^{2}$ per tree and from 0 to $0.54 \mathrm{~cm}^{2} \mathrm{~cm}^{-2}$ when corrected for tree basal area, averaging $30.2\left( \pm 1.81\right.$ S.E) $\mathrm{cm}^{2}$ and $0.056( \pm 0.002$ S.E $) \mathrm{cm}^{2} \mathrm{~cm}^{-2}$ for trees competing with lianas, and $13.9( \pm 1.81$ S.E $) \mathrm{cm}^{2}$ and $0.026( \pm 0.001 \mathrm{~S} . \mathrm{E}) \mathrm{cm}^{2} \mathrm{~cm}^{-2}$ for all trees. For basal area of lianas rooted within $1 \mathrm{~m}$ from the tree trunk these values ranged from $0-578 \mathrm{~cm}^{2}$ and $0-0.72 \mathrm{~cm}^{2} \mathrm{~cm}^{-2}$ per tree, with on average of $30.9( \pm 2.48$ S.E $) \mathrm{cm}^{2}$ and 0.068 $( \pm 0.004$ S.E $) \mathrm{cm}^{2} \mathrm{~cm}^{-2}$ for trees competing with lianas and 7.7 ( \pm 0.68 S.E) $\mathrm{cm}^{2}$ and $0.017\left( \pm 0.004\right.$ S.E) $\mathrm{cm}^{2} \mathrm{~cm}^{-2}$ for all trees.

\subsection{Multi-level LME model of tree diameter growth rate}

Of all variables included in the model, only below-ground competition with lianas did not significantly contribute to explaining variance in tree diameter growth $\left(\chi^{2}=1.1, P=0.29\right)$ nor did inclusion improve the AIC (3477 vs. 3477). The measure for below-ground competition with lianas was therefore excluded from the model. 
Table 1. Observed and median predicted above-ground biomass (AGB) increment (Mg dry weight ha ${ }^{-1} \mathrm{yr}^{-1}$ ) for current situation, for a scenario in which lianas are absent, and the average difference in AGB increment between the two scenarios. The 95\% prediction interval is shown between brackets. Only dicot trees measured in the 2003 census that survived until the 2006 census are included.

\begin{tabular}{|c|c|c|c|c|c|c|c|}
\hline \multirow{3}{*}{$\begin{array}{l}\text { Plot } \\
\text { TAM-01 }\end{array}$} & \multirow{3}{*}{$\begin{array}{c}\text { observed } \\
3.68\end{array}$} & \multicolumn{6}{|c|}{ Above-ground biomass increment ( $\mathrm{Mg}$ dry weight $\left.\mathrm{ha}^{-1} \mathrm{yr}^{-1}\right)$} \\
\hline & & \multicolumn{2}{|c|}{ Predicted current situation } & \multicolumn{2}{|c|}{ Predicted in absence of lianas } & \multicolumn{2}{|c|}{ Difference } \\
\hline & & 2.73 & $(1.51-4.41)$ & 3.06 & $(1.75-4.85)$ & & \\
\hline TAM-02 & 3.67 & 2.34 & $(1.17-3.94)$ & 2.73 & $(1.47-4.46)$ & & \\
\hline TAM-05 & 4.88 & 3.10 & $(1.65-5.11)$ & 3.55 & $(1.99-5.72)$ & & \\
\hline TAM-06 & 4.61 & 2.89 & $(1.61-4.64)$ & 3.20 & $(1.84-5.06)$ & & \\
\hline TAM-07 & 5.44 & 3.44 & $(1.97-5.45)$ & 3.85 & $(2.28-6.00)$ & & \\
\hline mean & 4.53 & 2.92 & $(1.59-4.75)$ & 3.30 & $(1.88-5.26)$ & 0.38 & $(0.29-0.51)$ \\
\hline
\end{tabular}

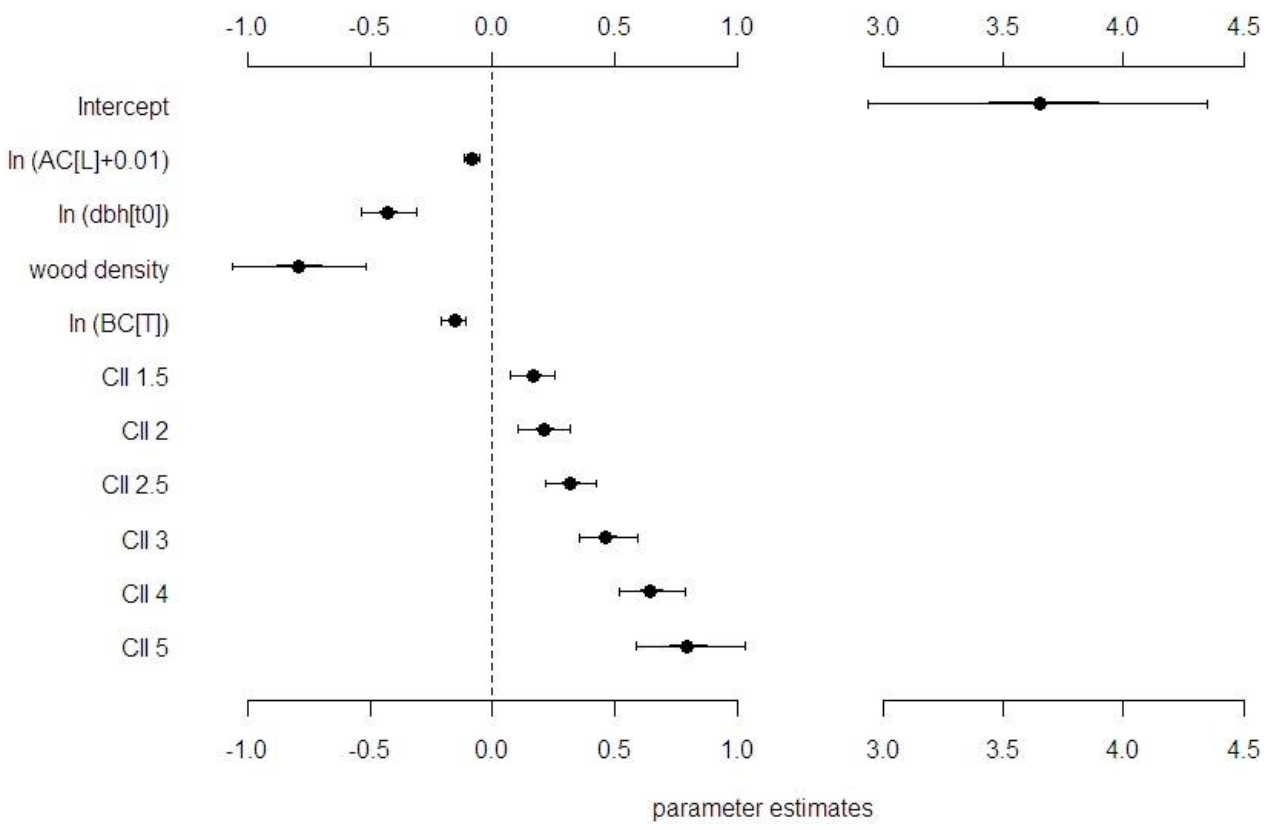

Fig. 1. Parameter estimates of the random effects of the multi-level Linear Mixed Effect (LME) model explaining tree diameter growth rate $\left(\mathrm{mm} \mathrm{yr}^{-1}\right)$. Bold lines and error bars indicate $50 \%$ and $95 \%$ confidence interval of the parameter estimates, respectively. None of the confidence interval overlaps zero (dashed line), indicating all contribute significantly to explaining tree diameter growth. AC $[\mathrm{L}]=$ aboveground competition with lianas, $\mathrm{dbh}[\mathrm{t} 0]=$ initial tree diameter, $\mathrm{BC}[\mathrm{T}]=$ below-ground competition with neighbouring trees, $\mathrm{CII}=\mathrm{crown}$ illumination index.

The final model (Eq. 6 excluding $\mathrm{BC}_{L}$ ) shows that aboveground competition with lianas, wood density, initial tree diameter and below-ground competition with neighbouring trees all significantly decrease tree growth, whilst tree growth was promoted for trees growing in higher light environments (Fig. 1a). Phylogeny and plot, included as random effects in the model, only attributed to $10.5 \%$ of the variation, with $9.4 \%$ explained by phylogeny $(4.1 \%$ by species, $0.1 \%$ by genera and $5.2 \%$ by families) and $1.1 \%$ by plot, indicating that $89.5 \%$ of the variation in tree growth rate is explained by differences between individual trees not related to these random effects. However, although their contribution to explaining the variation in tree diameter growth rate was lim- ited, inclusion of the random effects considerably decreased the AIC (AIC=3477) compared to a model without these effects (AIC $=3583$ ). The model generally fitted the observed data well, but has the tendency to under-predict tree growth rates greater than $10 \mathrm{~mm} \mathrm{yr}^{-1}$ - mostly experienced by larger trees growing in high light environments (Fig. 2). While this results in conservative estimates of median stand-level AGB increment, observed values fall within the $95 \%$ prediction interval of the model (Table 1). As the observed AGB increment was closer to the upper limit of the prediction interval than the median, we focus here on the predictions of the former. 

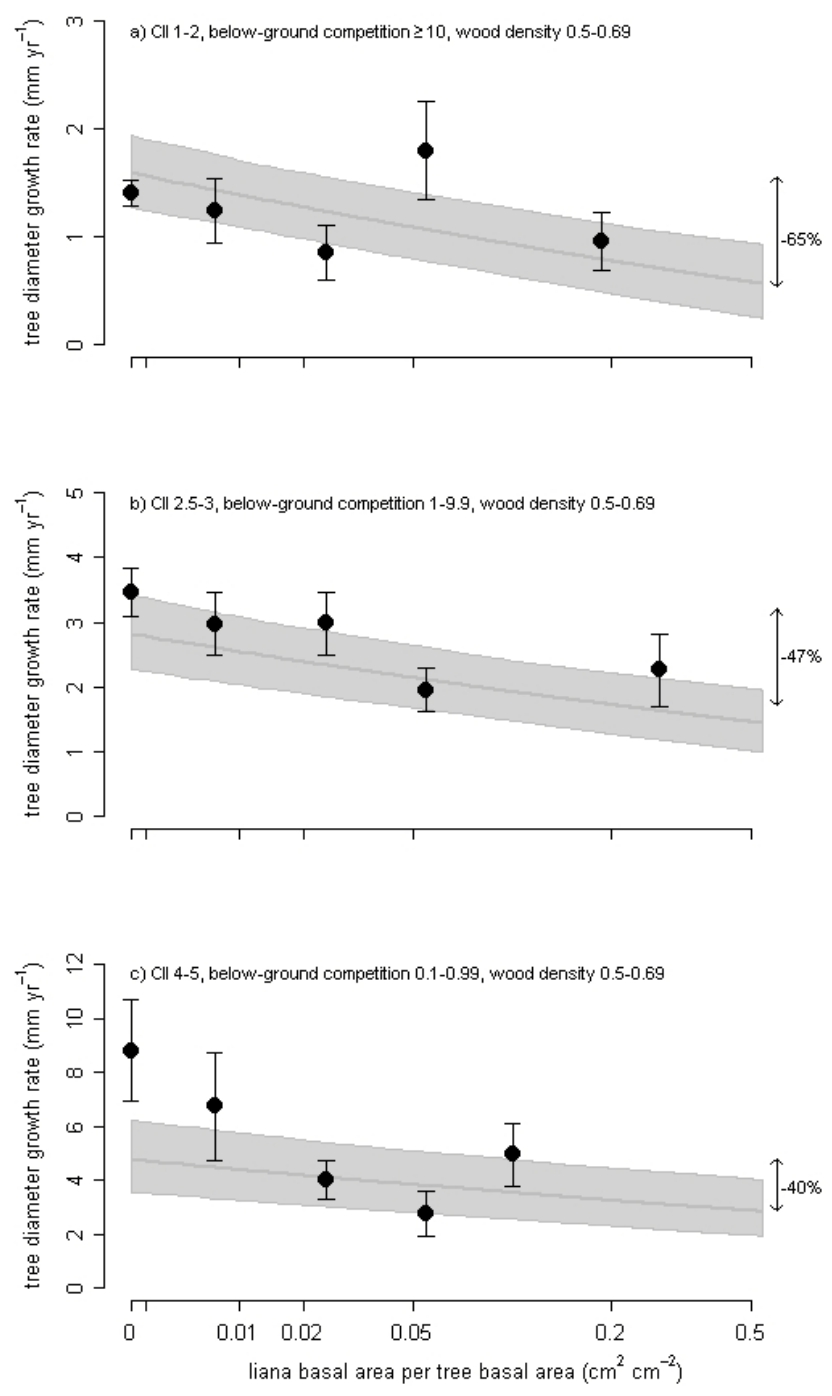

Fig. 2. Effect of lianas competition on tree diameter growth rates for trees with wood densities between $0.50-0.69$ and growing under different conditions (a) low light and high below-ground competition with neighbouring trees, (b) medium light and medium belowground competition, and (c) high light and low below-ground competition. Grey areas represent the $95 \%$ confidence interval of tree diameter growth rates predicted by the fixed effects model using median values of each fixed effect as an input variable of the model. Closed circles represent the average observed tree diameter growth rates for five classes of intensity of liana competition, located on the midpoint of each liana competition class. Error bars represent \pm 1 S.E. Percentages in right margin indicate the reduction in growth rate of trees severely competing with lianas $\left(>0.50 \mathrm{~cm}^{2} \mathrm{~cm}^{-2}\right)$ compared to trees not competing with lianas.

\subsection{Effect of lianas on tree growth}

Tree diameter growth rate decreased with increasing severity of above-ground liana competition (Fig. 2). The effect of the liana competition, however, was different for trees growing under different growing conditions. Trees growing in favourable conditions (i.e. high light and low below-ground competition with neighbouring trees) tended to be relatively less affected by lianas compared to trees that were experiencing low light conditions and severe competition with neighbouring trees for below-ground resources (Fig. 2). Compared to liana-free trees, the model indicates a reduction in tree diameter growth rate between 40 and $65 \%$ for trees with wood densities between 0.50 and $0.69 \mathrm{~g} \mathrm{~cm}^{-3}$ competing severely with lianas $\left(0.50 \mathrm{~cm}^{2} \mathrm{~cm}^{-2}\right)$ (Fig. 2). These percentages are slightly reduced for trees with lighter wood $(38-54 \%)$ and amplified for trees with higher wood densities (43-82\%).

\subsection{Effect of lianas on stand-level AGB increment}

On a stand-level, above-ground competition with lianas reduced tree AGB increment by an average $0.51 \mathrm{Mg}$ dry weight $\mathrm{ha}^{-1} \mathrm{yr}^{-1}$ (Table 1). This is equivalent to a liana-induced reduction in relative tree AGB growth of $\sim 10 \%$. As the fraction of carbon in woody tissue of trees is approximately 0.5 (cf. Clark et al., 2001), this implies that lianas reduce carbon gain by tree growth in the forests of Tambopata by $0.25 \mathrm{Mg}$ $\mathrm{C} \mathrm{ha}^{-1} \mathrm{yr}^{-1}$.

The above-ground biomass increment of lianas $\geq 10 \mathrm{~cm} d_{\max }$ and lianas $\geq 1 \mathrm{~cm} d_{\text {vert }}$ was 0.09 and $0.15 \mathrm{Mg}$ dry weight $\mathrm{ha}^{-1} \mathrm{yr}^{-1}$, respectively (Table 2). Assuming carbon content of lianas is comparable to that of trees, the carbon gain of tropical forests by growth of lianas is 0.04 and $0.07 \mathrm{Mg} \mathrm{C} \mathrm{ha}^{-1} \mathrm{yr}^{-1}$ for large lianas and lianas $\geq 1 \mathrm{~cm} d_{\mathrm{vert}}$, respectively. On average, liana growth of lianas $\geq 10 \mathrm{~cm} d_{\max }$ compensated for $\sim 17 \%$ and that of the population of lianas $\geq 1 \mathrm{~cm} d_{\mathrm{vert}}$ for $\sim 29 \%$ of the liana-induced reduction in stand-level tree growth. This indicates that lianas decreased overall average annual ecosystem AGB increment of tropical forests by $0.36 \mathrm{Mg}$ dry weight $\mathrm{ha}^{-1} \mathrm{yr}^{-1}$ and overall ecosystem carbon gain by $0.18 \mathrm{Mg} \mathrm{C} \mathrm{ha}^{-1} \mathrm{yr}^{-1}$.

\section{Discussion}

Our study provides the first stand-level estimate for the reduction in above-ground tree biomass increment caused by lianas in mature tropical forests, and the first estimate for the partial compensatory effect of liana growth on this reduction.

As expected, competition with lianas reduced tree diameter growth. This reduction, however, was mainly attributed to the effect of above-ground competition with lianas. Including our measure of below-ground competition did not significantly improve the model for tree growth, indicating that its effect was generally too small to detect. Several studies have shown the importance of below-ground liana competition on growth of juvenile trees (Dillenburg et al., 1993a, b; Schnitzer et al., 2005; Toledo-Aceves and Swaine, 2007), but this effect seems to disappear over time as trees mature (Dillenburg et al., 1995; Toledo-Aceves and Swaine, 2008), indicating that the competitive effect of lianas may shift as 
Table 2. Above-ground liana biomass (AGB, Mg dry weight ha $^{-1}$ ) for the census in 2003 and 2006 and liana AGB increment (Mg dry weight $\left.\mathrm{ha}^{-1} \mathrm{yr}^{-1}\right)$ for the associated census interval for lianas $\geq 10 \mathrm{~cm}$ maximum diameter $\left(d_{\max }\right)$ and lianas $\geq 1 \mathrm{~cm}$ at $1.30 \mathrm{~m}\left(d_{\mathrm{vert}}\right)$ (calculated by assuming lianas $\geq 10 \mathrm{~cm} d_{\max }$ represent $57 \%$ of the biomass of lianas $\geq 1 \mathrm{~cm} d_{\text {vert }}$; Phillips et al., 2005). Calculations are based upon lianas measured in the 2003 census that survived until the 2006 census.

\begin{tabular}{|c|c|c|c|c|c|c|}
\hline \multirow[t]{3}{*}{ Plot } & \multicolumn{4}{|c|}{ Above-ground biomass (Mg dry weight ha ${ }^{-1}$ ) } & \multicolumn{2}{|c|}{ Above-ground biomass increment (Mg dry weight $\left.\mathrm{ha}^{-1} \mathrm{yr}^{-1}\right)$} \\
\hline & \multicolumn{2}{|c|}{ Lianas $\geq 10 \mathrm{~cm} d_{\max }$} & \multicolumn{2}{|c|}{ Lianas $\geq 1 \mathrm{~cm} d_{\mathrm{vert}}$} & \multirow{2}{*}{ Lianas $\geq 10 \mathrm{~cm} d_{\max }$} & \multirow{2}{*}{ Lianas $\geq 1 \mathrm{~cm} d_{\mathrm{vert}}$} \\
\hline & 2003 & 2006 & 2003 & 2006 & & \\
\hline TAM-01 & 2.13 & 2.26 & 3.74 & 3.97 & 0.05 & 0.09 \\
\hline TAM-02 & 2.68 & 2.94 & 4.71 & 5.16 & 0.10 & 0.17 \\
\hline TAM-05 & 3.20 & 3.52 & 5.62 & 6.18 & 0.14 & 0.22 \\
\hline TAM-06 & 2.22 & 2.43 & 3.89 & 4.27 & 0.09 & 0.14 \\
\hline TAM-07 & 3.59 & 3.76 & 6.30 & 6.59 & 0.07 & 0.11 \\
\hline mean & 2.97 & 3.01 & 8.19 & 5.28 & 0.09 & 0.15 \\
\hline
\end{tabular}

a tree gets older. Rooting depths of lianas and trees become more pronounced with plant size and with lianas also generally rooting deeper than trees (Holbrook and Putz, 1996; Restom and Nepstad, 2004), the intensity of below-ground competition should reduce. Likewise, larger lianas may invest more of their resources in leaves (Putz, 1983; Gehring et al., 2004; Cai et al., 2007; Selaya et al., 2007), increasing the leaf area competition between lianas and trees and further making above-ground competition the dominant mechanism by which lianas reduce tree growth.

The lack of detectable below-ground competition between lianas and trees may also be influenced by our methodology, based upon the basal area of above-ground stems rooting within one metre from the tree trunk. This distance may, for example, not cover all below-ground liana-tree interactions. Furthermore, the correlative approach taken in this study is not sufficient to draw firm conclusions about the lack of below-ground competition between lianas and trees. An experimental approach would help to further explore the relative importance of the effect of above- and below-ground competition with lianas on adult tree growth. Especially as so far the sparse number of experimental studies focussing on the below-ground interactions between lianas and adult trees indicate that below-ground competition with lianas affects some tree species (Pérez-Salicrup and Barker, 2000), but may not be apparent in others (Barker and Pérez-Salicrup, 2000).

Competition with lianas affected inherently slow growing trees (i.e. dense-wooded trees) more than it affected trees with fastest growth rate potential (trees with low wood density). Furthermore, the relative effect of lianas was greater for trees growing in unfavourable conditions (Fig. 2). Lianas locate their leaves close to tree leaves, so intimately competing for leaf space with the tree (Stevens, 1987; Clark and Clark, 1990). Moreover, the low light transmittance of liana leaves may severely reduce the light available to tree leaves located underneath the liana canopy (Avalos et al., 1999), which may be a particular problem for trees already growing in low light conditions. Increasing intensity of liana competition further reduced tree diameter growth rate (Fig. 2), consistent with tree-level findings in Central America (Putz, 1984; Grauel and Putz, 2004; Finegan et al., 1999). The relative amount of liana basal area (liana basal area per tree basal area) that trees carried, however, did not seem to exceed $\sim 0.50 \mathrm{~cm}^{2} \mathrm{~cm}^{-2}$. A possible explanation for this result may reflect a biased sample of the most heavily infested trees - over the three year census interval the most moribund trees may have simply died. More data on liana-competition over time are required to determine whether this is indeed the case, but we already have direct evidence that large liana infestation strongly increases tree mortality risk in western Amazonia (Phillips et al., 2005).

On a stand-level, our model predictions suggest that in the tropical forests of Tambopata lianas reduced stand-level tree biomass increment by $0.51 \mathrm{Mg}$ dry weight $\mathrm{ha}^{-1} \mathrm{yr}^{-1}$, equivalent to $0.25 \mathrm{Mg} \mathrm{C} \mathrm{ha}^{-1} \mathrm{yr}^{-1}$ (Table 1), indicating that lianas reduce tree AGB increment and consequently carbon gain by approximately $10 \%$. Although the fact that lianas suppress tree growth is generally accepted (Putz, 1984; Clark and Clark, 1990; Gerwing, 2001; Grauel and Putz, 2004; Schnitzer et al., 2005; Campanello et al., 2007), little research has focussed on quantifying this effect at the stand-level. Only Gerwing (2001) compared tree growth between control stands and stands where lianas had been cut or burned. This study was conducted in logged forest, so the results may not be applicable to undisturbed mature tropical forests.

By themselves contributing to the overall stand-level AGB increment and carbon gain, lianas compensate partially for the liana-induced reduction in tree growth. For lianas $\geq 10 \mathrm{~cm} d_{\max }$ and lianas $\geq 1 \mathrm{~cm} d_{\text {vert }}$, we estimate above-ground biomass productivity of lianas to be 0.09 and $0.15 \mathrm{Mg} \mathrm{ha}^{-1} \mathrm{yr}^{-1}$ (Table 2), respectively, compensating for $\sim 17 \%$ and $\sim 29 \%$ of the liana-induced reduction in 
stand-level tree AGB productivity. However, there is likely to be some error in these estimates of above-ground productivity. Firstly, liana biomass estimates are based upon lianas $\geq 10 \mathrm{~cm} d_{\max }$ only, which excludes a large proportion of the liana stems as only few lianas reach the $10 \mathrm{~cm} d_{\max }$ cut-off point. As the growth rate of smaller lianas may differ from growth of lianas $\geq 10 \mathrm{~cm} d_{\max }$, total liana growth may have been slightly over- or underestimated. Secondly, like trees, lianas might invest more in photosynthetic material instead of in woody tissue once they reach a certain size and as the allometric equation used is only based upon a few large lianas (Schnitzer et al., 2006), the liana biomass and biomass increment may be overestimated. And thirdly, no data is available yet on the carbon content in woody liana tissue. The ability of lianas to replace stems by cloning and the requirement for flexible stems reduces the need for investment in often carbon-rich compounds (e.g. lignin) (Hegarty et al., 1991), which may result in a lower concentration of carbon compounds in their woody tissue. The carbon fraction of 0.5 we used to estimate carbon gain by lianas may therefore be too high. The compensatory effect of lianas may therefore be smaller than estimated. We conclude that the liana-induced reductions we report in combined tree and liana AGB productivity $\left(0.36 \mathrm{Mg}\right.$ dry weight $\left.\mathrm{ha}^{-1} \mathrm{yr}^{-1}\right)$ and carbon gain $\left(0.18 \mathrm{Mg} \mathrm{Cha}^{-1} \mathrm{yr}^{-1}\right)$ are probably conservative estimates.

The number of trees competing with lianas and the severity of the competition may be expected to increase over time due to the increasing liana pressure on neotropical forests (Phillips et al., 2002; Wright et al., 2004; Wright and Calderon, 2006). The relative basal area of large lianas increased notably in many western Amazonian locations, including doubling over the previous 20 years (Phillips et al., 2002). If this were to continue and also be reflected in smaller liana size-classes, over the next two decades the mean liana basal area/tree basal area, currently $0.026 \mathrm{~cm}^{2} \mathrm{~cm}^{-2}$ per tree, might conceivably attain $\sim 0.050 \mathrm{~cm}^{2} \mathrm{~cm}^{-2}$ per tree. Based upon our model (Fig. 1), this would suggest a further increase in the liana-induced stand-level reduction in tree above-ground biomass increment from $0.51 \mathrm{Mg}$ dry weight $\mathrm{ha}^{-1} \mathrm{yr}^{-1}$ (now) to $0.74 \mathrm{Mg}$ dry weight ha ${ }^{-1} \mathrm{yr}^{-1}$ (mid 2020's). If the liana-tree impact at Tambopata is representative of the entire Amazon forest $\left(\sim 5.28 \times 10^{8} \mathrm{ha}\right)$, this would imply a summed annual tree growth impact of $1.21 \times 10^{8} \mathrm{Mg} \mathrm{C}$, respectively, which most probably will only be partly compensated by the growth of lianas themselves. However, these estimates may be conservative, as they do not account for 1) any changes in the number and kinds of trees affected by lianas, and 2) the actual mortality impact of lianas. Increased liana infestation rates may result in more dense-wooded trees competing with lianas, as the risk of liana infestation is greater for high wood density trees (van der Heijden et al., 2008). In the current paper we also show that the relative growth reduction associated with a given quantum of liana infestation is more severe in dense-wooded trees than in light-wooded trees. More re- search is needed to determine whether the effect of lianas on tree growth rate found in Tambopata is representative of the whole Amazon region, but based upon this apparent impact of lianas on tree growth there is a clear risk that increases in liana dominance will have significant impacts on the ability of tropical forests to sequester carbon. Given this, and the hypothesized benefit to lianas of hotter, drier climates (Swaine and Grace, 2007; Schnitzer, 2005), it is perhaps unfortunate that no ecosystem vegetation model attempts to account for lianas.

\section{Conclusion}

This study provides the first stand-level estimates of the effect of lianas on stand-level above-ground biomass productivity and carbon gain of trees $\geq 10 \mathrm{~cm}$ diameter for a mature tropical forest. We show that by competing mainly aboveground with trees, lianas can reduce tree above-ground biomass growth rate by approximately $0.51 \mathrm{Mg}$ dry weight $\mathrm{ha}^{-1} \mathrm{yr}^{-1}$ or $0.25 \mathrm{Mg} \mathrm{C} \mathrm{ha}^{-1} \mathrm{yr}^{-1}$. With an above-ground biomass increment of $0.15 \mathrm{Mg} \mathrm{ha}^{-1} \mathrm{yr}^{-1}$ and a carbon gain of $0.07 \mathrm{Mg} \mathrm{C} \mathrm{ha} \mathrm{yr}^{-1}$, liana growth only compensates partly for this reduction. An increase in liana dominance is expected to increase the relative competition with lianas and increase the number of trees affected by lianas, which will lead to a further reduction of tree above-ground biomass increment in the future. Increasing liana dominance is likely to be a factor reducing the rate of carbon uptake of tropical forests, with potential consequences for the rate of increase of atmospheric carbon dioxide.

Acknowledgements. We thank Tatiana Boza Espinoza for help with liana data collection; the recensus teams of 2003 and 2006: Abel Monteagudo, Antonio Peña, María Ysabel Cazorla, Isau Huamantupa, Eurídice Honorio, Luis Valenzuela, Margot Huicho, Tim Baker, Javier Silva Espejo, Michael Garcia, Janira Gonzalez Espinosa; Gabriela López-Gonzalez for help with the RAINFOR database; and Tim Baker, Emanuel Gloor, Jerome Chave, Simon Queenborough, Lindsay Banin, and one anonymous reviewer for helpful discussions and comments on earlier versions of this manuscript. This research was possible through grants from the Explorer's Club, the Coalbourn Trust, and the Alberta Mennega Foundation, financial support from the University of Leeds and logistic support from the Instituto National para Recursos Naturales (INRENA) and Peruvian Safaris S.A. O.L.P. was supported by a NERC Grant and a Leverhulme Trust Research Fellowship.

Edited by: J. Grace

\section{References}

Avalos, G., Mulkey, S. S., and Kitajima, K.: Leaf optical properties of trees and lianas in the outer canopy of a tropical dry forest, Biotropica, 31, 517-520, 1999. 
Baker, T. R., Phillips, O. L., Malhi, Y., Almeida, S., Arroyo, L., Di Fiore, A., Erwin, T., Higuchi, N., Killeen, T. J., Laurance, S. G., Laurance, W. F., Lewis, S. L., Monteagudo, A., Neill, D. A., Núñez Vargas, P., Pitman, N. C. A., Natalino M. Silva, J., and Vásquez Martínez, R.: Increasing biomass in Amazonian forest plots, Phylos. T. Roy. Soc. B, 359, 353-365, 2004a.

Baker, T. R., Phillips, O. L., Malhi, Y., Almeida, S., Arroyo, L., Di Fiore, A., Erwin, T., Killeen, T., Laurance, S. G., Laurance, W. F., Lewis, S. L., Lloyd, J., Monteagudo, A., Neill, D., Patiño, S., Pitman, N., Silva, J. N. M., and Vásquez Martínez, R.: Variation in wood density determines spatial patterns in Amazonian forest biomass, Global Change Biol., 10, 545-562, 2004b.

Baker, T. R., Honorio Conorado, E. N., Phillips, O. L., Martin, J., van der Heijden, G. M. F., Garcia, M., and Silva Espejo, J.: Low stocks of coarse woody debris in a southwest Amazonian forest, Oecologia, 152, 2007.

Barker, M. G. and Pérez-Salicrup, D.: Comparative water relations of mature mahogany (Swietenia macrophylla) trees with and without lianas in a subhumid, seasonally dry forest in Bolivia, Tree Physiol., 20, 1167-1174, 2000.

Burnham, K. P. and Anderson, D. R.: Model selection and multimodel inference: a practical information-theoretic approach, Springer Science, New York, 2002.

Cai, Z.-Q., Poorter, L., Cao, K.-F., and Bongers, F.: Seedling growth strategies in Bauhinia species: comparing lianas and trees, Ann. Bot.-London, 100, 831-838, 2007.

Campanello, P. I., Garibaldi, J. F., Gatti, M. G., and Goldstein, G.: Lianas in a subtropical Atlantic Forest: Host preference and tree growth, Forest Ecol. Manag., 242, 250-259, 2007.

Campbell, E. J. F. and Newbery, D. M.: Ecological relationships between lianas and trees in lowland rain forest in Sabah, East Malaysia, J. Trop. Ecol., 9, 469-490, 1993.

Casper, B. and Jackson, R. B.: Plant competition underground, Annu. Rev. Ecol. Syst., 28, 545-570, 1997.

Chave, J., Andalo, C., Brown, S., Cairns, M. A., Chambers, J. Q., Eames, D., Folster, H., Fromard, F., Higuchi, N., Kira, T., Lescure, J.-P., Nelson, B. W., Ogawa, H., Puig, H., Riera, B., and Yamakura, T.: Tree allometry and improved estimation of carbon stocks and balance in tropical forests, Oecologia, 145, 8799, 2005.

Chave, J., Muller-Landau, H. C., Baker, T. R., Easdale, T. A., ter Steege, H., and Webb, C. O.: Regional and phylogenetic variation of wood density across 2,456 Neotropical tree species, Ecol. Appl., 16, 2356-2367, 2006.

Clark, D. A. and Clark, D. B.: Life history diversity of canopy and emergent trees in a Neotropical rain forest, Ecol. Monogr., 62, 315-344, 1992.

Clark, D. A., Brown, S., Kicklighter, D. W., Chambers, J. Q., Thomlinson, J. R., and Ni, J.: Measuring the net primary productivity in forests: concepts and field methods, Ecol. Appl., 11, 356-370, 2001.

Clark, D. B. and Clark, D. A.: Distribution and effects on tree growth of lianas and woody hemi-epiphytes in a Costa Rican tropical wet forest, J. Trop. Ecol., 6, 321-331, 1990.

Clinebell, R. R., Phillips, O. L., Gentry, A. H., Stark, N., and Zuuring, H.: Predictions of Neotropical tree and liana species richness from soil and climatic data, Biodivers. Conserv., 4, 56-90, 1995.

Coomes, D. A. and Allen, R. B.: Effect of size, competition and altitude on tree growth, J. Ecol., 95, 1084-1097, 2007.
Davies, S. J., Palmiotto, P. A., Ashton, P. S., Lee, H. S., and Lafrankie, J. V.: Comparative ecology of 11 sympatric species of Macaranga in Borneo: tree distribution in relation to horizontal and vertical resource heterogeneity, J. Ecol., 86, 662-673, 1998.

Dillenburg, L. R., Whigham, D. F., Teramura, A. H., and Forseth, I. N.: Effects of vine competition on availability of light, water, and nitrogen to a tree host (Liquidambar styraciflua), Am. J. Bot., 80, 244-252, 1993a.

Dillenburg, L. R., Whigham, D. F., Teramura, A. H., and Forseth, I. N.: Effect of below- and aboveground competition from the vines Lonicera japonica and Parthenocissus quinquefolia on the growth of the tree host Liquidambar styraciflua, Oecologia, 93 , 48-54, 1993b.

Dillenburg, L. R., Teramura, A. H., Forseth, I. N., and Whigham, D. F.: Photosynthetic and biomass allocation responses of Liquidambar styracifula (Hamamelidaceae) to vine competition, Am. J. Bot., 82, 454-461, 1995.

Enquist, B. J., West, G. B., Charnov, E. L., and Brown, J. H.: Allometric scaling of production and life-history variation in vascular plants, Nature, 401, 907-911, 1999.

Ewers, F. W. and Fisher, J. B.: Variation in vessel length and diameter in stems of six tropical and subtropical Lianas, Am. J. Bot., 76, 1452-1459, 1989.

Finegan, B., Camacho, M., and Zamora, N.: Diameter increment patterns among 106 tree species in a logged and silviculturally treated Costa Rican rain forest, Forest Ecol. Manag., 121, 159176, 1999.

Fisher, J. B. and Ewers, F. W.: Vessel dimensions in liana and tree species of Gnetum (Gnetales), Am. J. Bot., 82, 1350-1357, 1995.

Gehring, C., Park, S., and Denich, M.: Liana allometric biomass equations for Amazonian primary and secondary forest, Forest Ecol. Manag., 195, 96-83, 2004.

Gelman, A. and Hill, J.: Data analysis using regression and miltilevel/hierarchical models, Cambridge University Press, Cambridge, 2007.

Gentry, A. H.: Changes in plant community diversity and floristic composition on environmental and geographical gradients, Annals of the Missouri Botanical Garden, 75, 1-34, 1988.

Gentry, A. H.: Distribution and evolution of climbing plants, in: Biology of vines, edited by: Putz, F. E. and Mooney, H. A., Cambridge University Press, Cambridge, 3-49, 1991.

Gerwing, J. J. and Farias, D. L.: Integrating liana abundance and forest stature into an estimate of total aboveground biomass for an eastern Amazonian rainforest, J. Trop. Ecol., 16, 327-335, 2000.

Gerwing, J. J.: Testing liana cutting and controlled burning as silvicultural treatments for a logged forest in the eastern Amazon, J. Appl. Ecol., 38, 1264-1276, 2001.

Gerwing, J. J., Schnitzer, S. A., Burnham, R. J., Bongers, F., Chave, J., DeWalt, S. J., Ewango, C. E. N., Foster, R. B., Kenfack, D., Martinez-Ramos, M., Parren, M. P. E., Perez-Salicrup, D. R., Putz, F. E., and Thomas, D. W.: A standard protocol for liana censuses, Biotropica, 38, 256-261, 2006.

Goldstein, H.: Multilevel statistical models, 3rd ed., Oxford University Press, London, 2003.

Granados, J. and Körner, C.: In deep shade, elevated $\mathrm{CO}_{2}$ increases the vigor of tropical climbing plants, Global Change Biol., 8, 1109-1117, 2002. 
Grauel, W. T. and Putz, F. E.: Effects of lianas on growth and regeneration of Prioria copaifera in Darien, Panama, Forest Ecol. Manag., 190, 99-108, 2004.

Hegarty, M. P., Hegarty, E. E., and Gentry, A. H.: Secondary compounds in vines with an emphasis on those with defensive functions, in: Biology of vines, edited by: Putz, F. E. and Mooney, H. A., Cambridge University Press, Cambridge, UK, 1991.

Holbrook, N. M. and Putz, F. E.: Physiology of tropical vines and hemiepiphytes:plants that climb up and plants that climb down, in: Tropical Forest Plant Ecophysiology, edited by: Mulkey, S. S., Chazdon, R. L., and Smith, A. P., 1996.

Kainer, K. A., Wadt, L. H. O., Gomes-Sliva, D. A. P., and Capanu, M.: Liana loads and their association with Bertholletia excelsa fruit and nut production, diameter growth and crown attributes, J. Trop. Ecol., 22, 147-154, 2006.

Keeling, H. C. and Phillips, O. L.: A calibration method for the crown illumination index for assessing forest light environments, Forest Ecol. Manag., 242, 431-437, 2007.

King, D. A., Davies, S. J., Nur Supardi, M. N., and Tan, S.: Tree growth is related to light interception and wood density in two mixed dipterocarp forests of Malaysia, Funct. Ecol., 19, 445453, 2005

Lorimer, C. G.: Tests of age-independent competition indices for individual trees in natural hardwood stands, Forest Ecol. Manag., 6, 343-360, 1983.

Malhi, Y. and Wright, J.: Spatial patterns and recent trends in the climate of tropical rainforest regions, Phylos. T. Roy. Soc. B, 359, 311-329, 2004.

McCulloch, C. E. and Searle, S. R.: Generalized, linear and mixed models, John Wiley \& Sons Inc., New York, 2001.

Muller-Landau, H. C.: Interspecific and inter-site variation in wood specific gravity of tropical trees, Biotropica, 36, 20-32, 2004.

Pérez-Salicrup, D. and Barker, M. G.: Effect of liana cutting on water potential and growth of adult Senna multijuga (Ceasalpinioideae) trees in a Bolivian tropical forest, Oecologia, 124, 469475, 2000

Phillips, O. L., Vásquez Martínez, R., Arroyo, L., Baker, T. R., Killeen, T., Lewis, S. L., Malhi, Y., Mendoza, A. M., Neill, D., Vargas, P. N., Alexiades, M., Cerón, C., Flora, A. D., Erwin, T., Jardim, A., Palacios, W., Saldias, M., and Vinceti, B.: Increasing dominance of large lianas in Amazonian forests, Nature, 418, 770-774, 2002.

Phillips, O. L., Baker, T. R., Arroyo, L., Higuchi, N., Killeen, T., Laurance, W. F., Lewis, S. L., Lloyd, J., Terborgh, J., Vásquez Martínez, R., Alexiades, M., Almeida, S., Brown, S., Chave, J., Comiskey, J. A., Czimczik, C. I., Di Fiore, A., Erwin, T., Kuebler, C., Laurance, S. G., Nascimento, H. E. M., Olivier, J., Palacios, W., Patiño, S., Pitman, N., Quesada, C. A., Saldias, M., Torres Lezama, A., and Vinceti, B.: Pattern and process in Amazon tree turnover, 1976-2001, Phylos. T. Roy. Soc. B, 359, 381-407, 2004.

Phillips, O. L., Vásquez Martínez, R., Monteagudo Mendoza, A., Baker, T. R., and Núñez Vargas, P.: Large lianas as hyperdynamic elements of the tropical forest canopy, Ecology, 86, 1250-1258, 2005.

Pinheiro, J. C. and Bates, D. M.: Mixed-effects models in S and S-plus, Springer, New York, 2000.

Putz, F. E.: Liana biomass and leaf area of a "Tierra Firme" forest in the Rio Negro Basin, Venezuela, Biotropica, 15, 185-189, 1983.
Putz, F. E.: The natural history of lianas on Barro Colorado Island, Panama., Ecology, 65, 1713-1724, 1984.

Putz, F. E.: Silvicultural effects of lianas, in: Biology of vines, edited by: Putz, F. E. and Mooney, H. A., Cambridge University Press, Cambridge, UK, 493-501, 1991.

R Development Core team: R: a language and environment for statistical computing, R Foundation for Statistical Computing, Vienna, 2008.

Restom, T. G. and Nepstad, D. C.: Seedling growth dynamics of a deeply rooting liana in a secondary forest in eastern Amazonia, Forest Ecol. Manag., 190, 190-118, 2004.

Schnitzer, S. A.: A mechanistic explanation for global patterns of liana abundance and distribution, Am. Nat., 166, 262-276, 2005.

Schnitzer, S. A., Kuzee, M. E., and Bongers, F.: Disentangling above- and below-ground competition between lianas and trees in a tropical forest, J. Ecol., 93, 1115-1125, 2005.

Schnitzer, S. A., DeWalt, S. J., and Chave, J.: Censusing and measuring lianas: a qualitative comparison of the common methods, Biotropica, 38, 581-591, 2006.

Schwinning, S. and Weiner, J.: Mechanisms determining the degree of size asymmetry in competition among plants, Oecologia, 113, 447-455, 1998.

Selaya, N. G., Anten, N. P. R., Oomen, R. J., Matthies, M., and Werger, M. J. A.: Above-ground biomass investments and light interception of tropical forest trees and lianas early in succession, Ann. Bot.-London, 99, 141-151, 2007.

Sheil, D.: A critique of permanent plot methods and analysis with examples from Budongo Forest, Uganda, Forest Ecol. Manag., 77, 11-34, 1995.

Stevens, G. C.: Lianas as structural parasites: the Bursera simaruba example, Ecology, 68, 77-81, 1987.

Swaine, M. D. and Grace, J.: Lianas may be favoured by low rainfall: evidence from Ghana, Plant Ecol., 192, 271-276, 2007.

Toledo-Aceves, T. and Swaine, M. D.: Effect of three species of climber on the performance of Ceiba pentandra seedlings in gaps in a tropical forest in Ghana, J. Trop. Ecol., 23, 45-52, 2007.

Toledo-Aceves, T. and Swaine, M. D.: Above- and below-ground competition between the liana Acacia kamerunensis and tree seedlings in contrasting light environments, Plant Ecol., 196, 233-244, 2008.

Tomlinson, P. B.: Systematics and ecology of the Palmae, Annu. Rev. Ecol. Syst., 10, 85-107, 1979.

van der Heijden, G. M. F., Healey, J. R., and Phillips, O. L.: Infestation of trees by lianas in a tropical forest in Amazonian Peru, J. Veg. Sci., 19, 747-756, 2008.

Whigham, D. F.: The influence of vines on the growth of Liquidambar styraciflua L. (Sweetgum), Can. J. Forest Res., 14, 3739, 1984.

Wright, S. J., Calderón, O., Hernandéz, A., and Paton, S.: Are lianas increasing in importance in tropical forests? A 17-year record from Panama, Ecology, 85, 484-489, 2004.

Wright, S. J. and Calderon, O.: Seasonal, El Niño and longer term changes in flower and seed production in a moist tropical forest, Ecol. Lett., 9, 35-44, 2006.

Wright, S. J., Hernandez, A., and Condit, R.: The bushmeat harvest alters seedling banks by favouring lianas, large seeds and seed dispersed by bats, birds, and wind, Biotropica, 39, 363-371, 2007. 